\title{
The complacency of legality: Constitutionalist vulnerabilities to populist constituent power
}

\author{
Julian Scholtes ${ }^{*}$
}

(Received 31 December 2018; accepted 15 January 2019)

\begin{abstract}
What role do public law and liberal constitutionalism play in an era of political populism? This article approaches this question by exploring the concept of constituent power in the light of recent constitutional developments in countries with populist governments. It attempts to outline and contrast conceptions of constituent power as inherent in liberal constitutionalist and populist thinking, respectively. While constitutionalists draw heavily upon Kelsenian normativism in framing the way political power is generated, populists juxtapose this with a concept of constituent power that is inspired by Carl Schmitt's 'decisionist' view. The complacency of legality inherent in liberal constitutionalist thinking is susceptible to a populist challenge that draws attention to the necessity for the social embeddedness of any legal order. Populism, it is argued, exposes a core tension inherent in constitutionalism: How do constitutionalists reconcile their democratic aspirations with the simultaneous preclusion of certain political choices from the democratic realm? Populists can attack constitutionalism also because of the deficient conception of constituent power that underlies the latter. The article concludes that, where challenged by populists, public law can at some point no longer rely on its own force to defend itself. Its authority needs to be re-established from an extra-legal, pre-positive perspective. In an era of political populism, constitutionalist public law becomes a discourse that can challenge populism by means of the powerful reasons that inhere in the former.
\end{abstract}

Keywords: constituent power; the authority of public law; constitutional eternity

\section{A. Introduction}

Political populism appears to be omnipresent nowadays. From Viktor Orbán's pledge to build an illiberal state in Europe ${ }^{1}$ and the Polish assault on judicial independence, ${ }^{2}$ to Narendra Modi in India ${ }^{3}$ and Rodrigo Duterte in the Philippines, ${ }^{4}$ populists are challenging constitutional democracy everywhere. While the bulk of academic discussion of populism has taken place in political science, the legal sciences, and especially constitutional theory, have important contributions to make to the issue. This Article attempts to provide such a contribution by inquiring

\footnotetext{
*Julian Scholtes is PhD Researcher, European University Institute, Department of Law. Email: Julian.Scholtes@EUI.eu

${ }^{1}$ Honor Mahony, Orban Wants to Build "Illiberal State," EuOBSERVER (July 28, 2014), https://euobserver.com/political/ 125128

${ }^{2}$ Tomas Tadeusz Koncewicz, Constitutional Capture in Poland 2016 and Beyond: What is Next?, VerfassungSBLOG (Dec. 19, 2016), https://verfassungsblog.de/constitutional-capture-in-poland-2016-and-beyond-what-is-next/.

${ }^{3}$ Priya Chacko, The Right Turn in India: Authoritarianism, Populism and Neoliberalisation, 48 J. CONTEMP. AsIA 541 (2018).

${ }^{4}$ Nicole Curato, Flirting with Authoritarian Fantasies? Rodrigo Duterte and the New Terms of Philippine Populism, 47 J. Contemp. Asia 142 (2017).
} 
about the role that public law, as liberal constitutionalism, ${ }^{5}$ has in an era of political populism. Although populism is a global phenomenon, this Article focuses on populism in Europe, utilizing Hungary and Poland-and, to some extent, Turkey—as examples.

Recently, Martin Loughlin identified three main strands of public law, namely, the laws concerning "the acquisition and generation of political power ... the institutionalisation of political power, and ... the exercise of political power." 6 This Article implicitly structures itself along these three strands, albeit in reverse order. Part B provides a definition of political populism as it presents itself in Europe while briefly addressing the third strand of public law-the exercise of political power. Part C illustrates how populists generally challenge the authority of public law, thus addressing the institutionalization of political power. These two sections conclude that populism attacks public law at its root - that is, at its conception of constituent power and thus of the acquisition and generation of political power. Part D addresses the conclusion of the preceding sections by contrasting the normativist and decisionist conceptions of constituent power implicit in constitutionalism and populism, respectively. Accordingly, Part D argues that populists can attack constitutionalism because of the deficient conception of constituent power that underlies constitutionalism. Part E concludes that where populists challenge public law, public law can at some point no longer rely on its own force to fully defend itself. Its authority needs to be re-established from an extra-legal, pre-positive perspective. In an era of political populism, the role of public law is thus as a discourse that can challenge populism by means of the powerful reasons that inhere in public law.

\section{B. Populist politics in europe}

Populism is a political concept and must thus be defined politically. A prominent definition characterizes populism as:

[A] thin-centered ideology that considers society to be ultimately separated into two homogeneous and antagonistic camps, "the pure people" versus "the corrupt elite," and ... argues that politics should be an expression of the volonté générale ... of the people.

Populism is thin-centered in that it consists of a skeletal conceptual framework that usually attaches itself to more substantive ideologies of the host, such as nationalism or socialism. ${ }^{8}$ It is thus not necessarily a right-wing ideology — as is mostly the case in European politics—but, rather, it is something that takes on various forms and political leanings around the world. Nevertheless, what unites most populists is their exclusive moral claim to being representative of the people and their impulse to neatly frame all criticism directed against themselves as elitist. ${ }^{9}$ This "claim to represent the real or common people and to know their true interests" 10 is arguably the central tenet of populism.

In Europe, many iterations of populism are exclusionary ${ }^{11}$ in that they attach to the nationalist, far-right ideologies of the host. The central tenet of this exclusionary populism is that the people

\footnotetext{
${ }^{5}$ Some might criticize this hasty equation as prejudiced and oversimplifying. I have, however, decided to work with this normative conception of public law. A different approach would have amounted to an explanation of public law from a populist perspective - a task that I would rather leave to the populists themselves.

${ }^{6}$ Martin Loughlin, On Constituent Power, in Constitutionalism Beyond Liberalism 156 (Michael W. Dowdle \& Michael A. Wilkinson eds., 2017).

${ }^{7}$ Populism in Europe and the Americas: Threat Or Corrective for Democracy? 8 (Cas Mudde et al. eds, 2012).

${ }^{8} I d$. at 3.

${ }^{9}$ See Jan-Werner Müller, Populist Constitutions - A Contradiction in Terms?, VERFASSUNGSBLOG (Apr. 23, 2017), https://verfassungsblog.de/populist-constitutions-a-contradiction-in-terms/.

${ }^{10}$ Luigi Corrias, Populism in a Constitutional Key: Constituent Power, Popular Sovereignty and Constitutional Identity, 12 Eur. Const. L. Rev. 6, 11 (2016).

${ }^{11}$ See generally Cas Mudde \& Cristóbal Rovira Kaltwasser, Exclusionary vs. Inclusionary Populism: Comparing Contemporary Europe and Latin America, 48 Gov'T. \& Opposition 147 (2013).
} 
are under attack from a global elite that allegedly attempts to undermine their national and cultural identity through immigration, Europeanization and globalization. Accordingly, they advocate political platforms that pursue the curtailment of rights like freedom of religion, the right to asylum, and minority rights.

One may thus already arrive at an answer to the question that this Article poses: Where populists attempt to erode rights, the role of public law is to exercise one of its normal functionsnamely, constraining the exercise of political power. Constitutionalist public law scrutinizes political power through the exercise of practical reasoning and checks on political action to ensure conformity with constitutionally entrenched rights. Stopping at this ultimately shallow answer, however, forgoes the question entirely because such an answer only addresses the particular far-right host ideology, rather than populism itself. Similarly, an appropriate answer would also avoid conflating the question of populism with questions concerning judicial review and its merits. ${ }^{12}$ Indeed, there is a much deeper sense in which populism stands fundamentally at odds with constitutionalist public law.

\section{Populism and the eroding authority of public law}

Not only are populist platforms often at odds with constitutionally entrenched rights, but populists also reject the constraints on political power that emanate from these rights. In short, populism rejects constitutionalism. Populism "deems that nothing supersedes the general will of the people[.]"13 The power of courts is thus a significant thorn in the side of many populists. Populists brand courts as enemies of the people ${ }^{14}$ and lash out against unelected judges who "overstep[] their authority." 15 The populist conception of popular sovereignty favors a politics of immediacy ${ }^{16}$ unmediated by institutions that might interfere with the popular will. Parliamentary representation is deemed legitimate only insofar as it corresponds with what is deemed the volonté générale. ${ }^{17}$ Although in practice populists seemingly "have an opportunistic approach toward constitutionalism," ${ }^{18}$ selectively endorsing and rejecting aspects of constitutionalism, such a reading makes little sense from a legal perspective. Indeed, the only conclusion from a legal perspective is that populists reject constitutionalism ${ }^{19}$ because do not accept the authority of constitutional law.

Recalling Raz's conception of authority, authority is legitimate under two conditions. The first condition-the normal justification condition-is that "the subject would better conform to reasons that apply to him anyway... if he intends to be guided by the authority's directives than if he does not." ${ }^{20}$ The second condition-the independence condition-provides that "authority is legitimate only where acting by oneself is less important than conforming to reason[.]"21

Unsurprisingly, populists seem to reject these conditions with respect to public institutions. Where public institutions' directives are at odds with the general will, populists would maintain

\footnotetext{
${ }^{12}$ Müller, supra note 9.

${ }^{13}$ Cas Mudde, Are Populists Friends or Foes of Constitutionalism? 4 (2013), http://www.fljs.org/files/publications/ Mudde_0.pdf.

${ }^{14}$ James Slack, Enemies of the People: Fury Over "Out of Touch" Judges Who Have "Declared War on Democracy" by Defying 17.4m Brexit Voters and Who Could Trigger Constitutional Crisis, DaILY MAIL OnLINE (Nov. 3, 2016), http://www.dailymail. co.uk/news/article-3903436/Enemies-people-Fury-touch-judges-defied-17-4m-Brexit-voters-trigger-constitutional-crisis.html.

${ }^{15}$ James Chapman, Day We Stood Up to Europe: In An Unprecedented Move, MPs Reject European Court's Ruling that Prisoners Must Get the Vote, DAILY MAIL OnLINE (Feb. 11, 2011), http://www.dailymail.co.uk/news/article-1355640/ Prisoners-vote-MPs-reject-European-courts-ruling.html.

${ }^{16}$ Corrias, supra note 10 , at 19.

${ }^{17}$ Müller, supra note 9.

${ }^{18}$ Cristóbal Rovira Kaltwasser, Populism vs. Constitutionalism? Comparative Perspectives on Contemporary Western Europe, Latin America, AND the United States 1 (2013), https://www.fljs.org/files/publications/Kaltwasser.pdf.

${ }^{19}$ See also Gábor Halmai's contribution in this issue.

${ }^{20}$ Joseph Raz, The Problem of Authority: Revisiting the Service Conception, 90 MinN. L. REv. 1003, 1014 (2006).

${ }^{21} \mathrm{Id}$. at 1015 .
} 
that acting by oneself supersedes the reason at hand-in this case, constitutional legality. Further, for the populist, constitutional legality is not a reason that applies anyway because the general will must necessarily take precedence over any other reason. Populists do not recognize the authority of public law as legitimate, because in their view, the popular will precedes everything, including the constitutional order. In this sense, populism is not politics of the people as the constituted power, but rather an unmediated relationship with the constituent power. ${ }^{22}$ The result is that populists are politicizing the constitution, transforming it into a political topic like any other. Where public law previously represented the frame for political action, it has now become part of the canvas.

Accordingly, populists have, where able, pursued aggressive constitutional politics. After coming into power in Hungary in 2010, FIDESZ immediately started drafting a new constitution that was adopted only a year later. Shortly afterwards, the Hungarian parliament passed an amendment to the constitution barring the Constitutional Court from substantially reviewing constitutional amendments. As long as FIDESZ maintained a parliamentary supermajority, they could enact any law simply by amending the constitution, which they repeatedly did. ${ }^{23}$

The Polish PiS government, despite lacking the constitutional majority that FIDESZ held until 2014 (and holds again since 2018), nonetheless "embarked on a constitutional revolution under the cloak of statutory revision and piecemeal tinkering." ${ }^{24}$ In 2015, PiS unconstitutionally replaced three judges on the Polish Constitutional Tribunal by overwriting the appointments taken by the Sejm prior to the election. Although the President of the Constitutional Tribunal refused to admit these "anti-judges" 25 to sit with the Chamber, the President was replaced and the three subsequently took to the bench. The government also refuses to publish judgments that it considers "vitiated by ... procedural errors and lack[ing] legal basis." 26

Populists do not recognize the authority of public law as legitimate because they believe that the mandate of the general will should supersede considerations of constitutional legality. As illustrated by the examples of Hungary and Poland, public law, which is supposed to regulate the exercise of political action, is drawn into the political sphere through aggressive constitutional politics. The question that arises, then, is: Can public law nevertheless maintain its authority so that it may continue to exercise its normal function?

\section{A note on Turkey and constitutional eternity}

It seems impossible for constitutionalism to simply assert itself where there are no institutions committed to it, or, more generally speaking, where there is too big a rift between constitutional text and constitutional subject. Countries like Germany and, ironically, Turkey have attempted to fortify their constitutional order against those who want to undermine it from within through constitutional eternity clauses ${ }^{27}$ as well as doctrines of militant

\footnotetext{
${ }^{22}$ Corrias, supra note 10, at 9-10; see also Populism in Europe AND the Americas: Threat Or Corrective For DEMOCRACY, supra note 7, at 208 ("[P] opulist actors see 'the people' as an active entity, or ... the constituent power, that is, the main actor of a democratic regime when it comes to (re)founding and updating the higher legal norms and rules that regulate the exercise of power.").

${ }^{23}$ See generally Kriszta Kovács \& Gábor Attila Tóth, Hungary's Constitutional Transformation, 7 EuR. CONST. L. REV. 183 (2011).

${ }^{24}$ Koncewicz, supra note 2.

${ }^{25}$ Marcin Matczak, An Eye for an Eye: Law as an Instrument of Revenge in Poland, Verfassungsblog (Mar. 8, 2017), https://verfassungsblog.de/an-eye-for-an-eye-law-as-an-instrument-of-revenge-in-poland/.

${ }^{26}$ Koncewicz, supra note 2.

${ }^{27}$ Article 79(3) of the Grundgesetz bars all constitutional amendments that would alter the federal structure of the German state, the entrenchment of the principle of human dignity under Article 1, and the democratic and social nature of the German state as defined in Article 20. GRUNDGESETz [GG] [BASIC LAw], translation at http://www.gesetze-im-internet.de/englisch_gg/ index.html. Similarly, Article 4 of the Turkish Constitution protects the republican nature of the Turkish state and its characteristics as a "democratic, secular and social state governed by [the] rule of law, within the notions of public peace, national
} 
democracy ${ }^{28}$ that permit restricting freedom of speech and banning parties that wish to undermine the constitutional order. But, as the recent referendum in Turkey has shown, the promise of the eternal constitution may be in vain. Eternity clauses may protect text, but they cannot protect social and political reality. The idea that public law can constrain politics can only work if politics is willing to be thus constrained. What differentiates Germany from Turkey in this respect is that Germany has a strong constitutional culture-a Verfassungspatriotismus ${ }^{29}$ - that anchors constitutional principles to society, while Turkish constitutionalism has had to be lifted from its own grave in almost every decade of its history. ${ }^{30}$ The current Turkish Constitution of 1982 has arguably been in a legitimacy crisis since its inception. ${ }^{31}$ The precariousness of the Turkish constitutional trajectory, in combination with Tayyip Erdoğan's increasingly black-and-white post-coup populist rhetoric, are arguably central factors that have opened a gap for the introduction of the new presidential system. Where populists have politicized public law-as has been the case in Turkey, Poland, and Hungary-public law has been removed from the safe of constitutional entrenchment. There is no simple constitutional fiat one could rely on in order to assert its authority.

This is problematic for lawyers because lawyers love thinking in terms of legality. They take comfort in the "legal [fiction] that an answer to any issue can be found in the law." 32 Accordingly, they take the law as a given and presume the existence of the constitution as the most natural thing in the world. As the previous section has shown, however, constitutions cannot be taken for granted. Where populism erodes their authority, they often fail to bridge the gap between validity and effectiveness, between normativity and facticity. Constitutions-as constitutional text-thus seem to lack the sufficient scope to investigate the question at that this Article concerns itself with. To reach an answer, then, requires moving beyond, or before, the constitution to the concept of constituent power.

\section{Schmitt and Kelsen in Budapest}

Constituent power is what makes the constitution. Because there is no unified conception of constituent power, two implicit assumptions that were made throughout the previous sections need to be explained and discarded. First, any equivalence between constitutionalism and public law is void outside the specific constitutional frame. Second, assuming that there is a neat separation between the legal and the political is similarly void where there is no constitution to delimit one from the other.

The constitutionalist and populist conceptions of constituent power fundamentally differ from each other. As this Article argues, the reason constitutionalism is so vulnerable to populism lies in its conception of constituent power and the real implications it had on the development of constitutional law in Europe. Public law-in this Article's previous definition as public law underscored by liberal constitutionalism - can only fulfill its normal function and re-establish authority if it recognizes the weaknesses in its conception of constituent power.

solidarity and justice, respecting human rights, loyal to the nationalism of Atatürk, and based on the fundamental tenets set forth in the preamble[,]" Constitution of Turkey, Art. 2, as well as the territory, flag, language, and capital of the state, id. Art. 3.

${ }^{28}$ See Jan-Werner Müller, Militant Democracy, in The OXford Handbook of Comparative Constitutional LaW 1253 (Michel Rosenfeld \& András Sajó eds., 2012); see also Karl Loewenstein, Militant Democracy and Fundamental Rights, I, 31 Am. Pol. SCI. Rev. 417 (1937).

${ }^{29}$ See Jürgen Habermas, Appendix II: Citizenship and National Identity, in BETwEEN FACTS AND NORMS: CONTRIBUTIONS To A Discourse Theory of LAW AND Democracy 491, 491-515 (William Rehg trans., 1996).

${ }^{30}$ For a history of military coups in Turkey from a constitutional law perspective, see Ozan O. Varol, The Turkish "Model" of Civil-Military Relations, 11 INT'L J. CONST. L. 727 (2013).

${ }^{31}$ See Aslı Bâli, Shifting into Reverse: Turkish Constitutionalism under the AKP, 19 THEORY \& EvENT (Issue 1 Supplement) retrieved from https://muse.jhu.edu/article/610221 (2016).

${ }^{32}$ Martin Loughlin, The Idea of Public Law 50 (2004). 


\section{Normativism, constitutionalization, and the complacency of legality}

Probably the best starting point from which to understand normativism, the constitutionalist conception of constituent power, is Hans Kelsen's Pure Theory of Law. For Kelsen, "legal science is a science of norms." 33 As such, the law is strictly confined to the sphere of Sollen ("ought") because, in keeping with David Hume, no ought can be logically derived from an is. The law thus presents itself as a self-contained system of norms that derive their authority from a higher norm, resulting in a hierarchy. ${ }^{34}$ The ending point of the hierarchy, where "the chain of authorization runs out"35 is where Kelsen locates the Grundnorm - that is, the fundamental norm from which all other norms are derived, but which is not itself derived from any other norm. The Grundnorm is the hypothetical foundation of the legal system upon which the validity of all subsidiary law depends. ${ }^{36}$ The existence of the Grundnorm is simply presupposed because "it does not make sense to ask when it was created, or by whom, or how. These categories simply do not apply to it." ${ }^{\text {"T }}$ The question of its origin is one that goes beyond the ambit of the legal sciences: "Constituent power, the will that makes the constitution, is for Kelsen a political and not a legal issue." 38

This leads us to the normativist conception ${ }^{39}$ of constituent power: Once an order is constituted, once a basic norm is established, the question of constituent power vanishes. Norms derive their validity from other norms, and anything that stands outside the system of norms is incapable of affecting this system. Normativism "fashions itself on the autonomy of legal and constitutional ordering." ${ }^{40}$ Constituent power, for normativists, is not much more than a myth; ${ }^{41}$ it is akin to the unmoved mover or the big bang ${ }^{42}$ of a legal system. It must have been there, but that is all there is to it. What matters is what it sets in motion.

Within this conception of constituent power, even new constitutions are always founded on and derive their legality from prior constitutions. The German Grundgesetz and its intrinsically Kelsenian conception of constituent power illustrate this well: Article 146, the final Article of the Grundgesetz, states that the Grundgesetz will lose its validity on the day the German people decide on a new constitution. ${ }^{43}$ Constituent power is thus captured within constituted power. A prevalent interpretation goes even further in arguing that the German people's constitution-making power under Article 146 must be subject to the constraints of the eternity clause under Article 79(3). Essential elements of a future constitution are thus already constituted within the existing order. ${ }^{44}$

\footnotetext{
${ }^{33}$ Riccardo Guastini, Normativism or the Normative Theory of Legal Science: Some Epistemological Problems, in Normativity and Norms: Critical Perspectives on Kelsenian Themes 317 (Stanley L. Paulson ed., 1998).

${ }^{34}$ Hans Kelsen, Introduction to the Problems of Legal Theory: A Translation of the First Edition of the Reine Rechtslehre or Pure Theory of Law 63-6 (1997).

${ }^{35}$ Martin Loughlin, The Concept of Constituent Power, 13 Eur. J. Pol. ThEORY 218, 222 (2014).

${ }^{36} \mathrm{KeLSEN}$, supra note 34, at 50.

${ }^{37}$ Joseph Raz, Kelsen's Theory of the Basic Norm, in Normativity and Norms: Critical Perspectives on Kelsenian THEMES 50-1 (Stanley L. Paulson ed., 1998).

${ }^{38}$ Loughlin, supra note 6, at 157.

${ }^{39} \mathrm{It}$ is worth mentioning that normativism is not limited of positivist conceptions of law. David Dyzenhaus, for instance, legitimizes the authority of law with its inherent rationality, based upon the natural force of the principle of legality, rather than presupposing the existence of a Grundnorm. See generally David Dyzenhaus, The Politics of the Question of Constituent Power, in The Paradox of Constitutionalism: Constituent Power and Constitutional Form 129 (Martin Loughlin \& Neil Walker eds., 2008).

${ }^{40}$ Loughlin, supra note 6, at 152.

${ }^{41} I d$. at 157.

${ }^{42}$ See Tony Honoré, The Basic Norm of a Society, in Normativity and Norms: Critical Perspectives on Kelsenian THEMES 89, 101-02 (Stanley L Paulson ed., 1998) (making the same comparison).

${ }^{43}$ GRUNDGESETZ [GG] [BASIC LAw] art. 146, translation at http://www.gesetze-im-internet.de/englisch_gg/index.html.

${ }^{44}$ See generally Christoph Möllers, "We Are (Afraid of) the People:" Constituent Power in German Constitutionalism, in THE Paradox of Constitutionalism: Constituent Power and Constitutional Form 87 (Martin Loughlin \& Neil Walker eds., 2008).
} 
The normativist conception of constituent power links up with post-war European constitutionalism in that the latter strived to lock away certain parts of public life from the political sphere by framing them as constitutional. The necessary precondition for this was to prevent the constituent power from "[reasserting] itself from within the constitutional order." 45 This required eroding the concept of constituent power as far as possible in order to replace "a constitutionalism based on constituent power with one founded on legality." 46

Normativism can be regarded as the basis of the processes of constitutionalization ${ }^{47}$ that have taken place over the past decades. The positivization of rights and the establishment of the European transnational order are the two most eminent examples of these processes. The positivization of rights in national constitutional orders after World War II-a reaction to the horrors of totalitarianism - was part of the project to remove from the political sphere those parts of public life that were deemed untouchable. What Loughlin coins the rights revolution ${ }^{48}$ is the judicial unravelling of these rights as abstract norms into concrete legal rules which constitutionalize increasingly larger parts of the public sphere. ${ }^{49}$ Similarly, the Europeanization of the public sphere has taken place by judicial, rather than democratic or political means-on the one hand, by means of the rights jurisprudence of the European Court of Human Rights, and on the other hand, through the constitutionalisation of the European Communities by the European Court of Justice. The latter provides an especially vivid example of how far judicial law-making constitutionalized the European order through the development of the doctrines of supremacy and direct effect and the Court of Justice's self-empowerment through the back door to conduct de facto judicial review of national legislation. ${ }^{50}$

Normativism is the conceptual foundation for these developments. By framing issues as regulated by constitutionally sanctioned rules, issues could be safely and justifiably withdrawn from the ambit of democratic decision-making. Where constituent power has vanished, there is nothing but the authoritative legal order and the rules that emanate from it. Where the authority of law was presumed on the basis of the legal system's intrinsic ought qualities, liberal constitutionalist tenets could be "presented as a meta-theory which establishes the authoritative standards of legitimacy for the exercise of public power wherever it is located." ${ }^{51}$ Constitutionalist norms have legitimacy "not because they have been authorized by a people but because of the self-evident rationality of their claims." 52

Consequently, the normativist conception may likely run into problems when confronted with claims of democracy or popular sovereignty. Normativism diminishes the need for constituted order to be founded democratically. Democratic procedures cannot step outside of their legal frame and bring about an exercise of constituent power because constituent power, through the normativist lens, vanishes once an order is established. The processes of constitutionalization, enabled by a normativist conception of constituent power, further exacerbates this tension. In fact, one might suspect that constitutionalization is the result of a fear of democracy revolting against the flourishing of liberal constitutionalism. Indeed, as concerns some of the provisions included in post-war constitutions, Lon Fuller notes that "[O]ne suspects that the reason for their inclusion is ... a fear that they would not be able to survive the vicissitudes of an ordinary exercise of

\footnotetext{
${ }^{45}$ Dyzenhaus, supra note 39, at 129.

${ }^{46}$ Michael A. Wilkinson, The Reconstruction of Post-War Europe: Liberal Excesses, Democratic Deficiencies, in Constitutionalism Beyond Liberalism 38, 43 (Michael W. Dowdle \& Michael A. Wilkinson eds., 2017).

${ }^{47}$ Martin Loughlin, What Is Constitutionalisation?, in The Twilight of Constitutionalism? 47 (Petra Dobner \& Martin Loughlin eds., 2010).

${ }^{48}$ Loughlin, supra note 32 , at $125-28$.

${ }^{49} \mathrm{Id}$. at 127.

${ }^{50}$ See generally G. Federico Mancini, The Making of A Constitution For Europe, 26 Common MkT. L. ReV. 595 (1989) (relaying an account of the court-driven constitutionalization of the EU).

${ }^{51}$ Loughlin, supra note 46 , at 61.

${ }^{52} I d$.
} 
parliamentary power." 53 Similarly, European integration through law might have simply been a comfortable way to circumvent democratic procedure and "a masterly and opportune substitute for a real constitution... a convenient expedient for politics." 54

There is a complacency in the legality-based normativist axiomatic that can be easily exploited. If political issues could be constitutionalized, who is to say that the reverse is impossible? The idea that certain parts of public life could be entirely locked away from the reach of politics by framing them as constitutional is naive and formalistic. To use the words of Martin Loughlin, the consequence of constitutionalization is that "political critique of law can no longer come mainly from the outside; the moralization of law means that political critique must also come from within." 55 Populists can exploit this complacency of normativism by juxtaposing a Schmittian, decisionist conception of constituent power.

\section{Populism, Schmitt, and the second coming of constituent power}

For Carl Schmitt, Kelsen's ideological adversary, constituent power can never be based on a norm nor can it vanish. The basis of the constitution, in Schmitt's view, is "a political decision concerning the type and form of its own being." 56 The decision, the will, is where is and ought meet, and, consequently, Hume's problem does not come up. ${ }^{57}$ This decision is made by the people as a political unity. ${ }^{58}$ Accordingly, constituent power is exercised "according to the principle of democratic legitimacy through the free will of the people." ${ }^{\prime 9}$ Democracy, for Schmitt, is the basis of the constitution, as opposed to the constitution being the frame for democracy.

This leads Schmitt to conclude that constituent power does not recede once an order has been constituted. It remains tangible within the constituted order. Schmitt argues that constituent power "is not thereby expended and eliminated, because it was exercised once. The political decision... cannot have a reciprocal effect on its subject and eliminate its political existence. This political will remains alongside and above the constitution." 60 For Schmitt, the belief that the transformation of constituent power into constituted power signifies any kind of entropic, irreversible change is a fiction. A constitution is simply an expression of the political will at a certain point in time. The people "can change its forms and give itself continually new forms of political existence." ${ }^{61}$ What it never does, however, is "[subordinate] itself, its political existence, to a conclusive formation." 62

Populism is, albeit implicitly, founded on this decisionist conception of constituent power. Where democracy is not constituted within an order, but stands outside the order-an order it established and may re-establish-populists can present the deconstruction of a constitution as a democratic exercise in its purest form. Populists, in claiming to be the voice of the people, consider themselves to "ultimately not [be] bound by constitutional constraints because [the people are] the source from which the constitution derives its legitimacy." 63

Because decisionist constituent power is a formless formative capacity ${ }^{64}$ it is not bound by any legal principle that emanates from some prior constitution. Accordingly, popular decision can

\footnotetext{
${ }^{53}$ Lon L. Fuller, Positivism and Fidelity to Law: A Reply to Professor Hart, 71 Harv. L. ReV. 630, 643 (1958).

${ }^{54}$ Antonin Cohen, Constitutionalism Without Constitution: Transnational Elites Between Political Mobilization and Legal Expertise in the Making of a Constitution for Europe (1940s-1960s), 32 L. \& SoC. INQUIRY 109, 112 (2007).

${ }^{55}$ Loughlin, supra note 32, at 128.

${ }^{56}$ CARl SchmitT, CONSTitutional TheOry 125 (Jeffrey Seitzer trans., 2008).

${ }^{57}$ Id. at 64; see also Sylvie Delacroix, Schmitt's Critique of Kelsenian Normativism, 18 RATIO JuRIs 30 (2005).

${ }^{58}$ SCHMITT, supra note 56, at 138.

${ }^{59} \mathrm{Id}$. (mentioning a second type of legitimacy—dynastic legitimacy—which is, however, of limited relevance here).

${ }^{60} I d$. at $125-26$.

${ }^{61} \mathrm{Id}$. at 129.

${ }^{62} \mathrm{Id}$. at 128.

${ }^{63}$ Corrias, supra note 10 , at 9.

${ }^{64}$ SCHMITT, supra note 56 , at 129.
} 
undermine even the most fundamental principles of a constitution like the principle of legality. Ignoring court orders, as in the Polish example, can thus be presented not as a constitutional transgression, but as an exercise of sovereignty-a democratically legitimate decision partially re-founding the constitutional order. Similarly, there is no need for a new constitution to connect to previous ones. The preamble of the new Hungarian Constitution, for example, explicitly declares the Constitution of 1949-which was in force until 2011 albeit in a highly amended form-to be invalid, ${ }^{65}$ potentially leading to ex tunc nullity of all laws based on the previous constitution, including case law from the Constitutional Court. ${ }^{66}$ Populists, in their own view, are not politicizing the constitution-they are simply exercising the constituent power that was naturally vested in the people in the first place. For populists, then, the role of public law is merely instrumental. Public law is not an end in itself and does not institutionalize any objective moral or rational principles. Its role is to serve the popular will.

Decisionism presents a radical inversion of the constitutionalist aspiration to contain democracy in law. In doing so, it exposes a core weakness of its normativist conception of constituent power: How do constitutionalists reconcile their democratic aspirations with the simultaneous preclusion of certain political choices from the democratic realm? How can the people be the sovereign, but at the same time not exercise their sovereignty? ${ }^{27}$ Normativism does not have an explanation for this. It simply "marginalizes the significance of democratic foundation." ${ }^{68}$ Leaning on the complacency of legality, constitutionalism merely assumes that the order is constituted and there is no escaping it.

If the assumption normativism made was a strong one, one that was manifestly evident, there would be less of a problem. But the strict separation of legal and sociological reality that normativism posits on the back of the is-ought problem is something that can hardly be rationally defended. The law is not automatic; it requires people who believe in its authority to execute it faithfully. The constitution is not a self-executing simulation with fixed parameters, but, rather, a loosely-meshed, highly permeable structure. The human condition of indeterminacy is one that not even the purest of theories of law could eliminate. The plasticity of values and identities produces ever-changing iterations of law that may be homogeneous in text, but are ultimately heterogeneous in effectiveness. ${ }^{69}$ What is not written in a constitution is often just as important as what is written ${ }^{70}$ because constitutional practice is just as important as-if not even more important than-constitutional text. Eliding the above-stated problem through the complacency of legality is in itself problematic. Populists can use this deficiency of normativism to exploit the human condition of indeterminacy in its most radical legal form - that is, as the people's constituent power.

\section{Verfassungsvoraussetzungen and public law as discourse}

The above conundrum inherent in constitutional democracy is a prominent theme discussed in one form or another in modern constitutional theory. Loughlin and Walker call it "the paradox of constitutionalism."71 Christodoulidis, with some variation, refers to it as "the aporia of

\footnotetext{
${ }^{65}$ Magyarország Alaptörvénye [The Fundamental law of Hungary], Alaptörvény.

${ }^{66}$ Eur. Consult. Ass., Opinion on the New Constitution, 87 $7^{\text {th }}$ Sess., Doc. No. 618, para. 35 (2011).

${ }^{67}$ Joseph De MAistre, STUdy ON SOVEREIGNTy (1794), http://maistre.uni.cx/sovereignty.html.

${ }^{68}$ Loughlin, supra note 6, at 153.

${ }^{69}$ Vaguely based on statements made by Hans Lindahl. See Hans Lindahl, The Purposiveness of Law: Two Concepts of Representation in the European Union, 17 L. \& PHIL. 481, 498-99 (1998).

${ }^{70}$ See Michael Foley, The Silence of Constitutions: Gaps, “Abeyances," and Political Temperament in the MAINTENANCE OF GOVERNMENT (1989).

${ }^{71}$ The Paradox of Constitutionalism: Constituent Power and Constitutional Form 1-8 (Martin Loughlin \& Neil Walker eds., 2008).
} 
sovereignty." 72 This problem, then, seems to be the key to the question posited above concerning the authority of constitutionalism and, consequently, to the question of the role of public law in an era of political populism. Within constitutional democracy inheres a tension between constituted and constituent power, between people and institutions, between democracy and law.

Constitutionalists must ultimately accept that this tension cannot be resolved through legal means. Populism creates a political discourse that extends beyond its legal frame, but the legal frame is unable to contain this discourse. Despite all the efforts of constitutionalists, the political realm extends into constitutional matters. ${ }^{73}$ To believe that constitutional rigidity would be able to contain the tension inherent in modern constitutionalism is illusory. At worst, it only exacerbates the tension. James Bryce writes that "[n]othing human is immortal; and constitution-makers would do well to remember that the less they presume on the long life of their work the longer it is likely to live." 74 Constitutionalists must accept "the political space [as] incorporating an unresolved dialectic of determinacy and indeterminacy, of closure and openness." ${ }^{\text {" }}$

Ultimately, any constitution rests on conditions that it cannot establish of itself, as famously pointed out by Ernst-Wolfgang Böckenförde, whose dictum is worth being recited at length:

The liberal ... secularized state lives by prerequisites which it cannot guarantee itself. This is the great adventure it has undertaken for freedom's sake. As a liberal state it can only endure if the freedom it bestows on its citizens takes some regulation from the interior, both from a moral substance of the individuals and a certain homogeneity of society at large. On the other hand, it cannot by itself procure these interior forces of regulation, that is not with its own means such as legal compulsion and authoritative decree. Doing so, it would surrender its liberal character... . ${ }^{76}$

The German term Verfassungsvoraussetzungen-constitutional prerequisites-encapsulates the essence of what Böckenförde identified. ${ }^{77}$ The liberal constitution cannot guarantee its own existence because it rests on conditions that are prior to the constitution and thus out of its own reach. Within Böckenförde's statement lies an implicit acknowledgement that Schmitt had a point in arguing that the people continue to be present within the constituted order as a constituent power. If they do not support the values and the tenets of constitutional democracy, then constitutional democracy cannot survive. The paradox of constitutionalism can thus only be alleviated, but never fully resolved. It is alleviated when the people appreciate the value of constitutionalism and, to frame it in Razian terms, believe that the reasons behind democratic constraints apply to them. The emergence of populism as a political force does not create any new tensions, it merely highlights the tension that is inherent in constitutional democracy in the first place.

But this acknowledgement of Schmitt does not imply that constitutionalists must surrender to populists. Rather, they must abandon the complacency of legality and embrace public law in public discourse. There are strong reasons from an intrinsic perspective for restraining democracy within the constitutional order. But where populists gain enough power to reshape this order, the people are drawn from a constituted into a constituent state where constitutional democracy

\footnotetext{
${ }^{72}$ Emilios A. Christodoulidis, The Aporia of Sovereignty: On the Representation of the People in Constitutional Discourse, 12 KING's C.L.J. 111, 122 (2001).

${ }^{73}$ Loughlin, supra note 6, at 166.

${ }^{74} 1$ James Bryce, Studies in History and Jurisprudence 177 (1901).

${ }^{75}$ Loughlin, supra note 6, at 166-67.

${ }^{76}$ Ernst-Wolfgang Böckenförde, Die Entstehung Des Staates Als Vorgang Der Säkularisation, in SäKULARISATION UND Utopie, 65 Geburtstag 42 (1967), translated in Böckenförde Dilemma, Wikipedia, http://en.wikipedia.org/wiki/ Böckenförde_dilemma (last visited Feb. 11, 2019) (emphasis omitted).

${ }^{77}$ See Ulrich Jan Schröder, Wovon Der Staat Lebt: Verfassungsvoraussetzungen Vom Vormärz Bis Zum Grundgesetz, 65 JURISTEN ZEITUNG 869 (2010).
} 
is unable to defend itself by its own means. Legality can only operate within a positive frame. Where this frame is rejected by participants in political discourse, constitutionalism must be justified by reasons that are prior to legality. Constitutionalists must stop believing that the reasons on which the authority of public law is supposed to rest are self-evident, and instead start embracing as much in political engagement. In an era of political populism, public law is a discourse. As such, it has a powerful role to fulfil in dismantling the populist threat to constitutionalism.

\section{E. Conclusion: A call to arms}

Some lawyers might not like the conclusion drawn in this Article because it goes beyond the bubble of legality that the law depends on. Others still might criticize the approach and instead argue the principle of legality is a more fundamental rational that renders questions of constituent power redundant. ${ }^{78}$

But the argument laid out above is, at the bottom of it, a relatively straightforward one: Legality is only an argument within the constitutional system that it structures. Populists question the system and erode the authority of public law. Where this authority is sufficiently eroded, as in Hungary, Poland, and Turkey, legality can no longer be as much of an argument. Accordingly, public law, as constitutionalism, can no longer assert itself by way of the principle of legality. Rather, those who wish to defend public law must assert it in political discourse.

The normativist conception of constituent power takes legality for granted because it presupposes the existence of the frame. Because constitutions, according to normativists, can only arise from prior constitutions, normativists believe that constituent power vanishes once an order is constituted. This is the fundamental weakness of normativism that makes it "a peculiarly inadequate conception of constitutional thought."79 It denies that legal and sociological realities interact with one another. Populists can exploit this weakness by juxtaposing normativism with decisionism, which posits the primacy of constituent over constituted power, and thus of sociological over legal reality.

Rather than surrendering to populism once the bubble of legality has burst, constitutionalists should acknowledge that Schmitt had a point in arguing that where law and sociological reality are out of touch, the law becomes but a piece of paper. What remains is the decision. The conclusion that can be drawn rests in a single, overly lengthy, German word: Verfassungsvoraussetzungen. Constitutionalists must defend public law in political discourse in order to help secure the prerequisites that constitutional democracy needs to survive, but cannot guarantee by its own force. Public law, in this era of political populism, is a discourse. It is not defended in court, it is defended in the streets.

\footnotetext{
${ }^{78}$ See also Dyzenhaus, supra note 39.

${ }^{79}$ Loughlin, supra note 6, at 159.
}

Cite this article: Scholtes J (2019). The complacency of legality: Constitutionalist vulnerabilities to populist constituent power. German Law Journal 20, 351-361. https://doi.org/10.1017/glj.2019.26 